the trend towards increased consumption of precooked and other processed foods. If the standard of living continues to rise and manual work to decrease it is reasonable to conclude that the pattern of food habits of the whole population will in the long term approach more closely that of the richest group (Class Ai of the National Food Survey), which now have a 'much greater consumption of liquid milk, cheese, meat, fish, green and other vegetables and fruit' than the rest of the population (Ministry of Agriculture, Fisheries and Food: National Food Survey Committee, r960), though National Food Survey records for the last 5 years provide no evidence that this is happening yet: food habits are slow to change and the working-class diet may still be influenced by memories of the thirties (Abrams, 1959). Finally, it seems that nutritional considerations are more likely to play their part through the actions of food manufacturers, and perhaps the Government, than through deliberate changes made by consumers in their eating habits.

\title{
REFERENCES
}

Abrams, Mark (1959). The Teenage Consumer. LPE Paper No. 5. London: London Press Exchange Ltd.

Anonymous (1960). Hotel and Restaurant Management, February, p. I7.

Crawford, W. \& Broadley, H. (1938). The People's Food. London: William Heinemann Ltd.

Harries, J. M. (1956). Bull. int. Inst. Refrig. Annex 1956-1, p. 121.

Industrial Welfare Society (Incorporated) (1958). Sixth Catering Survey October-November I957. London: Industrial Welfare Society (Incorporated).

Lawton, F. J. (1959). The Times. Supplement on Britain's Food, March 1959.

Ministry of Agriculture, Fisheries and Food: National Food Survey Committee. (1957). Domestic Food Consumption and Expenditure, 1955. London: H.M. Stationery Office.

Ministry of Agriculture, Fisheries and Food: National Food Survey Committee. (1959). Domestic Food Consumption and Expenditure, 1957. London: H.M. Stationery Office.

Ministry of Agriculture, Fisheries and Food: National Food Survey Committee. (1960). Domestic Food Consumption and Expenditure, 1958. London: H.M. Stationery Office.

Schulz, T. (1960). Bull. Oxf. Univ. Inst. Statist. 22, I43.

Warren, G. C. [editor] (1958). The Foods We Eat. London: Cassell \& Co. Ltd.

Wright, N. C. (1958). Roy. Soc. Hlth F. 78, 256.

\section{Diet of London busmen-a sample study}

\section{By E. Mary Bramwell, Social Medicine Research Unit (Medical Research Council) London Hospital, London, E.I}

The diet of London busmen is being studied as part of a research project on coronary heart disease of middle-aged men in different occupations. Drivers of double-decker buses have a higher incidence of a more severe type of coronary disease than conductors and often develop it at an earlier age (Morris, Heady, Raffle, Roberts \& Parks, I953 $a, b)$. Drivers are also on an average taller, heavier and fatter than conductors (Kagan, I960). A dietary study was undertaken to see if differences could be discovered between the meal patterns and food habits of these two groups, and comparisons have been made of the main nutrients in the diet. This paper is a report of work in progress and results are therefore provisional. 
The dietary study is being carried out on a sample of men who have previously co-operated in a medical study. Sixty-one men aged 34-49 have so far taken part in the survey; fifty-three of them have kept good and reliable log books of all food and drink taken during 7 consecutive days. A further three who were approached refused to co-operate. All food eaten at home has been weighed; samples of food in the London Transport canteens have been weighed by a dietitian; food eaten elsewhere is described as fully as possible.

Busmen are shift workers and work a different shift (or 'turn') each week. An early turn may start as early as 5 a.m. and last till the afternoon; a late turn starts in the afternoon and may continue till after midnight. There are also middle turns and a 'spread over', the latter covering morning and evening rush hours and allowing time off in the middle of the day. To eliminate the effects of the different turns on food habits, all men carry out the survey during a week when they are working a late turn, that is, starting work after 2 p.m. Where possible one or two rest days are included in the 7 days. Often, however, men work on their rest day. There are therefore a number of men who have worked a different turn on $I$ or 2 days of the survey week.

\section{General pattern of diet}

The general pattern is one of a limited and fixed routine. It appears from questioning that the majority of the men have an habitual food pattern which varies little from day to day or week to week, and the effect of the different turns seems to be more on the timing of the meal than on its contents. They like plain foods and there is little variety.

Table I. Breakfast pattern of fifty-three London busmen (twenty-seven drivers and twenty-six conductors) aged 34-49 (1957-60)

Food eaten five or more times
$\quad$ a week
Bread and butter only
Cereal or porridge
Cooked breakfast
Porridge and cooked breakfast
No fixed pattern
No breakfast (tea only)
Two courses

\begin{tabular}{|c|c|}
\hline $\begin{array}{l}\text { No. of } \\
\text { drivers }\end{array}$ & $\begin{array}{l}\text { No. of } \\
\text { conductors }\end{array}$ \\
\hline $\left.\begin{array}{l}3 \\
3 \\
7 \\
1\end{array}\right\}$ II & $\left.\begin{array}{l}2 \\
5 \\
6 \\
-\end{array}\right\}_{I I}$ \\
\hline 9 & I0 \\
\hline $\begin{array}{r}4 \\
10\end{array}$ & $\begin{array}{l}3 \\
6\end{array}$ \\
\hline
\end{tabular}

Breakfast. Breakfast is a routine meal for two-thirds of the busmen conforming to the same pattern for most of the week (Table $\mathrm{I}$ ). Some of them have a cup of tea but nothing to eat except sometimes a biscuit. A few have a plain breakfast of bread or toast with butter or margarine. Nearly half the men regularly have either a cereal breakfast food or a cooked breakfast; most of the drivers in this group have bread or toast as well, giving a two-course breakfast, but only half the conductors in the group have a second course. Only one man regularly had three courses, i.e. cereal, cooked item and bread and butter.

Midday. The midday meal is the main meal of the day for these busmen. Almost all of them regularly have either a meat, fish, egg or cheese dish with vegetables. 
The popular image of busmen eating large quantities of fried fish and chips has not been borne out. One-third of them ate no fish during the survey week, the rest ate it only once or twice, many of them having it boiled or baked, and often with boiled potatoes or other vegetables instead of chips. Meat pies are eaten with greater frequency than fried fish, two-thirds of the men having them once or twice a week. But many of these meat pies are eaten in the canteens as a snack during working hours and not at the main midday meal.

'Puddings' are eaten regularly by just over one-third of the men and those most popular are fruit tart and stewed and tinned fruit with custard. Many of the busmen have bread, cake or biscuits instead of a pudding and many have nothing to follow their main dish.

Mid-turn break. During working hours there are frequent breaks between journeys when the driver and conductor may have a cup of tea and sometimes a biscuit or cake, but most of the food eaten at work is taken at the main break halfway through the turn. This is frequently a sandwich meal-half the men having sandwiches regularly, mostly brought from home. The sandwich fillings are nearly always meat, cheese or egg. They often have cake or fresh fruit as well.

One-third of the men regularly have a cooked dish during working hours, some living near enough to the garage to enable them to go home for their break. This cooked dish may be a quickly fried one, such as bacon, eggs or sausages, or it may be a meat pie or sometimes meat and vegetables or salad.

Meals, snacks and cups of tea taken during working hours account for nearly $30 \%$ of the daily calorie intake.

Late evening. On returning home at night after work most of the busmen have something to drink. Generally this is a cup of tea or a milk drink but sometimes it is a glass of beer. In addition, $30 \%$ of them have a snack which may be a sandwich, or a quickly cooked dish such as bacon and eggs, or a breakfast cereal. Many others have biscuits or a slice of cake.

Sunday. Sunday is a day that has a definite meal pattern setting it apart from other days irrespective of whether it is a rest day or a working day. It is a feast day and generally the meals have more courses than on weekdays. Occasionally, when it is a rest day, the times of the meals are so changed that the net result is fewer meals, but larger than on weekdays.

Breakfast on Sundays includes a cooked item for many men who do not generally have a cooked breakfast during the week. Sunday dinner for the great majority is a

Table 2. Main differences between weekday and Sunday meal patterns of fifty-three London busmen (twenty-seven drivers and twenty-six conductors) aged 34-49 (1957-60)

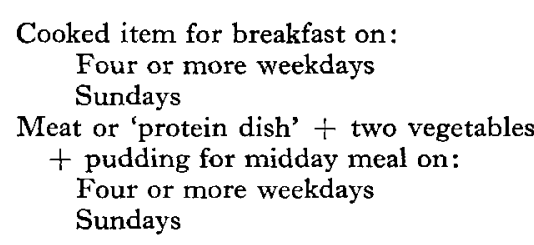

$\begin{array}{cc}\text { Drivers } & \text { Conductors } \\ \text { 10 } & 6 \\ \text { I8 } & 14 \\ & \\ 8 & 7 \\ 21 & 20\end{array}$


two-course meal and consists of meat with at least two vegetables and a pudding. Only a quarter of the men have this pattern regularly on weekdays (Table 2).

As many wives go out to work, Sunday is an especially important family day.

Beverages. The most popular drink amongst busmen is undoubtedly tea. The number of cups of tea drunk per week by these fifty-three men ranged from eleven to ninety-five, the mean being forty-six, i.e. nearly seven a day. This seems to be about the national average for adults (Ministry of Agriculture, Fisheries and Food: National Food Survey Committee 1960 ) on the basis that I lb of tea makes $180-200$ cups.

Alcohol consumption was very low and confined almost entirely to beer. Average consumption was $\mathbf{I} \cdot \mathbf{2}$ pints/head weekly which compares with a national average for men of 4.7 pints (Market Research Department, Odhams Press Ltd, I960). Only a third of the men drank any alcohol, which may partly be due to the survey's being carried out during a late-turn week. We have no reason to believe that busmen in the survey were underestimating their consumption.

Summary. Food patterns of these drivers and conductors were very similar, possibly reflecting the similarity in social environment and in income of the two groups. Their food is plain with little variety and few trimmings.

\section{Nutrients}

Intake. The nutrient content of the diet of drivers and conductors is virtually the same (Table 3 ) for when there is a difference between the values it is too small to be significant. The similarity of calorie intake is surprising for it is estimated that the energy expenditure at work of conductors is $300-500 \mathrm{kcal} /$ day greater than of drivers. An attempt is being made to discover whether drivers are more active during their leisure hours, or whether the difference in physique counteracts the effect of difference in physical activity. Judged very roughly from the distribution of uniform sizes more than twice as many drivers as conductors become fat during middle age (Morris, 1959). The number of men who have so far taken part in this survey is small but there is no indication at present of change in intake with increase in age.

Table 3. Mean daily intake of calories and nutrients of fifty-three London busmen (twenty-seven drivers and twenty-six conductors) aged 34-49 (1957-60)

$\begin{array}{lrc} & \text { Drivers } & \text { Conductors } \\ \text { Calories }(\mathrm{kcal}) & 2850 & 2790 \\ \text { Protein }(\mathrm{g}) & 83 & 8 \mathrm{I} \\ \text { Total fat }(\mathrm{g}) & \mathrm{I} 28 & \mathrm{1} 20 \\ \text { Animal fat }(\mathrm{g}) \text { (excluding dairy fat) } & 5 \mathrm{I} & 45 \\ \text { Carbohydrate }(\mathrm{g}) & 337 & 34 \mathrm{I}\end{array}$

Sources of nutrients. The sources from which the busmen derive their calories show once again a similarity between drivers and conductors (Table 4 ). They obtain more than a quarter of their calories from bread and butter (or margarine); onefifth comes from the main protein foods, meat, fish, eggs and cheese, which are eaten mainly at the midday meal or as sandwich fillings; a further one-fifth comes from milk and sugar, which is taken almost entirely in cups of tea or milk drinks. Biscuits $20(1) 4$ 
cakes and pastries contribute a tenth. Potatoes and puddings are the only other appreciable sources of calories.

Table 4. Food sources from which calories are derived, expressed as a percentage of total calorie intake, by fifty-three London busmen (twenty-seven drivers and twenty-six conductors) aged 34-49 (1957-60)

\begin{tabular}{|c|c|c|}
\hline $\begin{array}{l}\text { Bread } \\
\text { Spreading fat }\end{array}$ & $\left.\begin{array}{l}\text { Drivers } \\
17 \\
10\end{array}\right\} 27$ & $\begin{array}{l}\text { Conductors } \\
\left.\begin{array}{r}8 \\
9\end{array}\right\} 27\end{array}$ \\
\hline $\begin{array}{l}\text { Meat (including meat from pies) } \\
\text { Fish (excluding batters and coatings) } \\
\text { Cheese } \\
\text { Eggs (excluding fat for frying) }\end{array}$ & $\left.\begin{array}{r}16 \\
1 \\
2 \\
3\end{array}\right\} 22$ & $\left.\begin{array}{r}13 \\
1 \\
3 \\
2\end{array}\right\} 19$ \\
\hline $\begin{array}{l}\text { Milk } \\
\text { Sugar }\end{array}$ & $\left.\begin{array}{r}8 \\
12\end{array}\right\} 20$ & $\left.\begin{array}{r}7 \\
12\end{array}\right\} I 9$ \\
\hline Biscuits, cakes and pastries (including pastry from pies and tarts) & II & I3 \\
\hline $\begin{array}{l}\text { Potatoes (excluding fat for frying) } \\
\text { Puddings (steamed, baked and milk) } \\
\text { Vegetables, fruit and nuts } \\
\text { Cooking fats (used for frying) } \\
\text { Other foods }\end{array}$ & $\left.\begin{array}{l}5 \\
3 \\
3 \\
2 \\
7\end{array}\right\} 20$ & $\left.\begin{array}{l}5 \\
4 \\
3 \\
3 \\
7\end{array}\right\} 22$ \\
\hline
\end{tabular}

\section{Attitudes}

As a group these London busmen seldom had fads and fancies about foods. A few were trying to lose weight or had been ulcer patients at one time and modified their diet a little. But most of them ate whatever was available at home or in the canteen and seemed to think very little about it.

\section{Summary}

Drivers of London's double-decker buses have more coronary heart disease than the more physically active conductors; they are also taller, heavier and fatter. A sample diet study based on a week's individual weighed survey is in progress to see whether the diets of the two groups are different. At the present time no significant differences have been found in their nutrient intake and the food patterns are very similar.

I would like to express my thanks to all in London Transport who have co-operated so generously in this study; to Dr Kagan who carried out the medical survey of the busmen to which my own study is attached; to the Food Science and Atomic Energy Division of the Ministry of Agriculture, Fisheries and Food for help in the calculation of nutrients; and to other members of the Social Medicine Research Unit for their help.

\section{REFERENCES}

Kagan, A. R. (1960). Proc. R. Soc. Med. 53, I8.

Market Research Department, Odhams Press Ltd (1960). Daily Herald Readers and The Market for Beer and Stout, p. 27. London: Odhams Press Ltd.

Morris, J. N. (1959). A.M.A. Arch. intern. Med. 104, 903. 
Morris, J. N., Heady, J. A., Raffle, P. A. B., Roberts, C. G. \& Parks, J. W. (1953a). Lancet, 265, 1053. Morris, J. N., Heady, J. A., Raffle, P. A. B., Roberts, C. G. \& Parks, J. W. (r953b). Lancet, 265, i I I I. Ministry of Agriculture, Fisheries and Food: National Food Survey Committee. (1960). Domestic Food Consumption and Expenditure, 1958, p. 64. London: H.M. Stationery Office.

\section{Food habits in pregnancy}

\section{By Nan Taggart, Obstetric Medicine Research Unit (Medical Research Council), Maternity Hospital, Aberdeen}

Many factors, geographical, social, economic and cultural, combine to determine human dietary habits, which vary widely between individuals and between groups. Any changes, quantitative or qualitative, which may take place as a result of pregnancy will be superimposed on pre-existing food habits. The changes may occur spontaneously, or they may occur in consequence of education or other outside influence.

\section{Background variations in food habits}

Differences in food habits between economic groups in this country were first highlighted in Food, Health and Income (Orr, 1937), and are now summarized annually in reports from the Ministry of Agriculture, Fisheries and Food. A marketing research organization has recently described some of the regional as well

Table I. Percentage distributions of meal patterns in three social classes of Aberdeen primigravidae, 1950-53

\begin{tabular}{|c|c|c|c|}
\hline \multirow{3}{*}{ Type of meal } & \multicolumn{3}{|c|}{ Social class* } \\
\hline & I and II $(76)$ & III $(187)$ & IV and $V(46 \mathrm{I})$ \\
\hline & \multicolumn{3}{|c|}{ Breakfasts on weekdays } \\
\hline None & 0.2 & $2 \cdot 5$ & $2 \cdot 5$ \\
\hline Tea and roll & $2 x \cdot 7$ & $44 \cdot 5$ & $58 \cdot I$ \\
\hline Porridge or cereal & 50.0 & $4 I \cdot 2$ & $30 \cdot 2$ \\
\hline Cooked dish without cereal & $15 \cdot 8$ & 10.0 & $8 \cdot 5$ \\
\hline Two-course & $12 \cdot 3$ & $\mathrm{I} \cdot 8$ & 0.7 \\
\hline \multicolumn{4}{|c|}{ Breakfasts on Sundays } \\
\hline None & 0 & $2 \cdot 7$ & $\mathbf{I} \cdot 3$ \\
\hline Tea and roll & 145 & $16 \cdot 0$ & $16 \cdot 5$ \\
\hline Porridge and cereal & $22 \cdot 4$ & I $1 \cdot 8$ & $8 \cdot 9$ \\
\hline Cooked dish without cereal & $44 \cdot 7$ & $65 \cdot 8$ & $70 \cdot 7$ \\
\hline Two-course & 184 & $3 \cdot 7$ & $2 \cdot 6$ \\
\hline \multicolumn{4}{|c|}{ Midday meals for whole week } \\
\hline None & $x \cdot 3$ & 0.6 & 0.7 \\
\hline One-course & $7 \cdot 0$ & $19 \cdot 0$ & $3 I \cdot 6$ \\
\hline Two-course & $60 \cdot 0$ & $60 \cdot 8$ & $53 \cdot 0$ \\
\hline Three-course & $3 x \cdot 7$ & $19 \cdot 6$ & 14.7 \\
\hline \multicolumn{4}{|c|}{ Evening meals for whole week } \\
\hline None & $\mathrm{I} \cdot 9$ & 0.7 & $x \cdot 4$ \\
\hline Plain tea & 13.7 & $8 \cdot 4$ & $5 \cdot 5$ \\
\hline High tea & $77 \cdot 3$ & $88 \cdot 6$ & 90.9 \\
\hline Dinner & $7 \cdot 1$ & $2 \cdot 3$ & $2 \cdot 2$ \\
\hline
\end{tabular}

* Figures in parentheses are the numbers of women. 